\title{
Influence of Proline Priming on Antioxidative Potential and Ionic Distribution and its Relationship with salt Tolerance of Wheat
}

\author{
F. ShafiQ*, S.H. RaZA, A. BibI, I. Khan and M. IQbaL \\ Department of Botany, Government College University Faisalabad, Punjab, Pakistan \\ (Received 26 April 2017; Accepted 14 August 2017; \\ Communicated by A. Pécsváradi)
}

\begin{abstract}
Mechanisms involved in salt tolerance urge exploration and investigation of genotypic variation to assist future breeding programs. Comparative examination of ten wheat cultivars for salt tolerance and their response towards proline-seed-priming was performed. Exposure of wheat seedlings to salinity resulted in prominent reduction in root and shoot growth attributes of all cultivars. Furthermore, decrease in the chlorophyll contents was evident although this varied among cultivars. Wheat seedlings grown from proline pre-treated seeds exhibited improved photosynthetic pigments, besides this response was also cultivar and concentration dependent. Generally, salt stressed plants exhibited higher antioxidant enzyme activities. Proline priming significantly influenced antioxidant activities, however, its magnitude varied. The peroxidase activity varied among wheat cultivars that were evident from the analysis of POD activity on Native-PAGE gel. Salinity caused the accumulation of $\mathrm{Na}^{+}$in the roots and the magnitude of $\mathrm{Na}^{+}$translocation to the shoot was cultivar dependent. Similarly, $\mathrm{K}^{+}$uptake and its distribution among root and shoot varied. Priming treatments affected ion distribution of $\mathrm{Na}^{+}$and $\mathrm{K}^{+}$but inter-cultivar variations were evident. Conclusively, all the cultivars investigated exhibited differential response to salinity and proline seed pre-treatments. However, the proline-priming mediated improvements in growth and antioxidant enzyme activities contributed to stress tolerance which partly relied on the ability of the plant to uptake sodium and its partitioning in the roots. Of the cultivars tested, Faisalabad-08 and Bhakhar-2002 were ranked as relatively salt tolerant and the cvs. AARI-10, MH-97 and Auqab-2000 as relatively salt sensitive.
\end{abstract}

Keywords: catalase, peroxidase, proline, priming, salinity, superoxide dismutase, wheat

\section{Introduction}

Salinity is a global agricultural problem mainly associated with arid and semi-arid regions (Schleiff 2008). About 20 percent of the total irrigated and 6 percent of the global agricultural land is declared as salt affected (FAO 2008; Sileshi and Kibebew 2016). Elevated soil salt levels suppress plant growth and productivity posing a serious threat to agriculture and food sources (Koevoets et al. 2016; Daliakopoulos et al. 2016). Of the total area under wheat cultivation in Pakistan, a significant area is severely salt affected

*Corresponding author; E-mail: fahadsheikh1800@gmail.com 
(Murtaza et al. 2017). In general, salinity induces metabolic imbalance / oxidative stress that in turn damage vital cellular components including DNA and lipids (Apel and Hirt 2004). In opposition, enzymatic and non-enzymatic antioxidant defense system counter oxidative stress (Mittler 2002). It is proposed that plants exhibiting higher activities of antioxidant enzymes conferred resistance to oxidative damage (Hernandez et al. 2009).

Salt tolerance mechanisms are broadly classified into three main categories viz. osmotic tolerance, ion exclusion and tissue tolerance (Roy et al. 2014; Forni et al. 2017). Salinity tolerance mechanisms in plants are still unresolved despite of extensive research and success in developing tolerant genotypes is so far limited (Roy et al. 2014). There is no authentic criterion for the screening/ identification of salt tolerance due to extensive genetic variability. Specific changes initiated when salinity stress is exerted and these continue until maturity stages (Munns 2002). Fast, reliable and cost effective methods for screening salt tolerance at early stages are required. For this purpose, physiological/ biochemical markers should be identified in order to develop salt tolerant genotypes (Roy et al. 2014).

Wheat is an economically vital cereal crop classified as moderately salt tolerant. More than half of the protein and dietary calorie requirements of approximately one third of the world's population are provided by bread wheat (Dhanda et al. 2004). Wheat plants cultivated on saline soils show suppressed growth and gaseous exchange attributes at vegetative, booting and reproductive stages (Robin et al. 2016).

Proline is a multi-functional amino acid with exceptional conformational rigidity. It accumulated in plant species under various abiotic stresses such as drought, salinity, heavy metal and oxidative stress (Szabados and Savoure 2009). Involvement of proline in osmo-regulation is substantial and its accumulation under abiotic stress conditions is often used as a selection criterion for salt tolerance (Ueda et al. 2007; Szabados and Savoure 2009). Alternatively, its exogenous application could promote salt tolerance in plants. Accordingly we investigated that whether and to what extent proline seed invigoration could modulate growth and bio-chemical attributes including activities of antioxidant enzymes of salt stressed wheat. Furthermore, the immediate response of wheat seedlings of different cultivars during salt induced osmotic stress (initial stage of salinity) is examined and reported.

\section{Materials and Methods}

A sand culture experiment was performed with three experimental factors i.e., wheat cultivars, priming treatments, salinity levels. Seeds of ten wheat cultivars viz. Auqab-2000, Faisalabad-08, Lasani-08, AARI-10, MH-97, Sehar-2006, Pasban-90, Ufaq-2002, Shafaq-2006 and Bhakhar-2002 were primed ( 8 h) with L-proline solutions (un-primed, hydro-primed, 4 and $8 \mathrm{mM}$ proline). Surface sterilized $\left(0.1 \% \mathrm{HgCl}_{2}\right.$ for $3-4$ minutes $)$ were sown in plastic pots $(500 \mathrm{~mL})$ filled with washed sand and after germination the seedlings were allowed to establish for further 10 days. The seedlings were subjected to salinity stress at 0 and $150 \mathrm{mM} \mathrm{NaCl}$ concentrations (Iqbal and Ashraf 2013). Growth and 
biochemical attributes of wheat plants were investigated after 10 days of $\mathrm{NaCl}$ treatments (20 d old plants).

The antioxidant enzymes activities were determined from crude enzyme extract. Fresh leaf material $(0.2 \mathrm{~g})$ was homogenized in potassium-phosphate buffer $(200 \mathrm{mM}$; $\mathrm{pH} 7.8)$ containing insoluble PVP-40 (1\%) and EDTA $(1 \mathrm{mM})$ using chilled mortar and pestle under ice cold conditions and centrifuged at $12,000 \mathrm{~g}$ for 25 min at $4{ }^{\circ} \mathrm{C}$. The SOD activity was recorded by detection of inhibition in the photochemical reduction of NBT (Nitroblue tetrazolium chloride) at $560 \mathrm{~nm}$ (Giannopolitis and Ries 1977). The CAT activity was recorded by monitoring the decomposition of hydrogen peroxide $\left(\mathrm{H}_{2} \mathrm{O}_{2}\right)$ after every $20 \mathrm{~s}$ for 180 seconds at $240 \mathrm{~nm}$ (Aebi 1984). The POD activity was recorded by monitoring the oxidation of guaiacol to form a colored product tetraguaicol at $470 \mathrm{~nm}$ after every $20 \mathrm{~s}$ for 180 seconds (Chance and Maehly 1955). The enzyme activities are finally expressed in $\mathrm{U} \mathrm{mg}^{-1}$ protein basis. Guaiacol peroxidase (POD) isoforms were separated by Native-PAGE using Wealtec Mini Electrophoresis System (USA) using discontinuous system of Laemmli (1970) under non-denaturating conditions. The staining and detection of POD activity on native-PAGE gels was performed (Van Loon 1971).

Chlorophyll contents were determined using acetone $(80 \%)$ fresh leaf extracts and expressed in $\mathrm{mg} \mathrm{g}^{-1}$ fresh weight (Arnon 1949). Furthermore, the analysis of $\mathrm{Na}^{+}$and $\mathrm{K}^{+}$ ions from the digested plant samples (Wolf 1982) was carried out with the aid of flame photometer (Jenway PFP-7, U.K). The concentrations of the $\mathrm{Na}^{+}$and $\mathrm{K}^{+}$were calculated from standard curves and the ion contents were expressed in $\mathrm{mg} \mathrm{g}^{-1}$ dry weight (DW). The data was subjected to analysis of variance using COSTAT software using CRD design while differences among means were assessed by DMR test using M-Stat software (MSTAT Development Team 2013).

\section{Results}

\section{Effect of proline seed priming on growth}

Under salinity, all the cultivars exhibited prominent reduction $(P \leq 0.05)$ while plants grown from proline-primed seeds exhibited better shoot growth attributes. Briefly, maximum reduction in the shoot length was recorded for cv. Ufaq-02 while cv. Lasani-08 exhibited minimum reduction (Fig. S1*). Likewise, higher values of dry biomass under salinity were evident in plants raised from seeds pre-treated with L-proline (Fig. 1). Shoot length was positively correlated with shoot FW and DW $\left(\mathrm{R}^{2}=0.48 *\right.$ and $\left.0.40 *\right)$. Similarly, shoot FW was positively linked with shoot DW $\left(\mathrm{R}^{2}=0.87 * * *\right)$ and root FW is linked with root DW $\left(\mathrm{R}^{2}=0.45 *\right.$; Table S2). Overall under salinity, L-proline at $4 \mathrm{mM}$ concentration improved shoot growth of cvs. Auqab-2000, Sehar-2006, Ufaq-2002 and MH-97, while 8 $\mathrm{mM}$ was effective for cvs. Bhakhar-02, Ufaq-02, Auqab-2000 and MH-97. Prominent reduction in wheat root growth attributes was recorded under salinity (Fig. S2). Similar pattern was evident for dry biomass in response to addition of $\mathrm{NaCl}$ (Fig. 1). Wheat plants grown from proline (4 mM) improved the root length of all cultivars (Fig. S2).

*Further details about the Electronic Supplementary Material (ESM) can be found at the end of the article. 


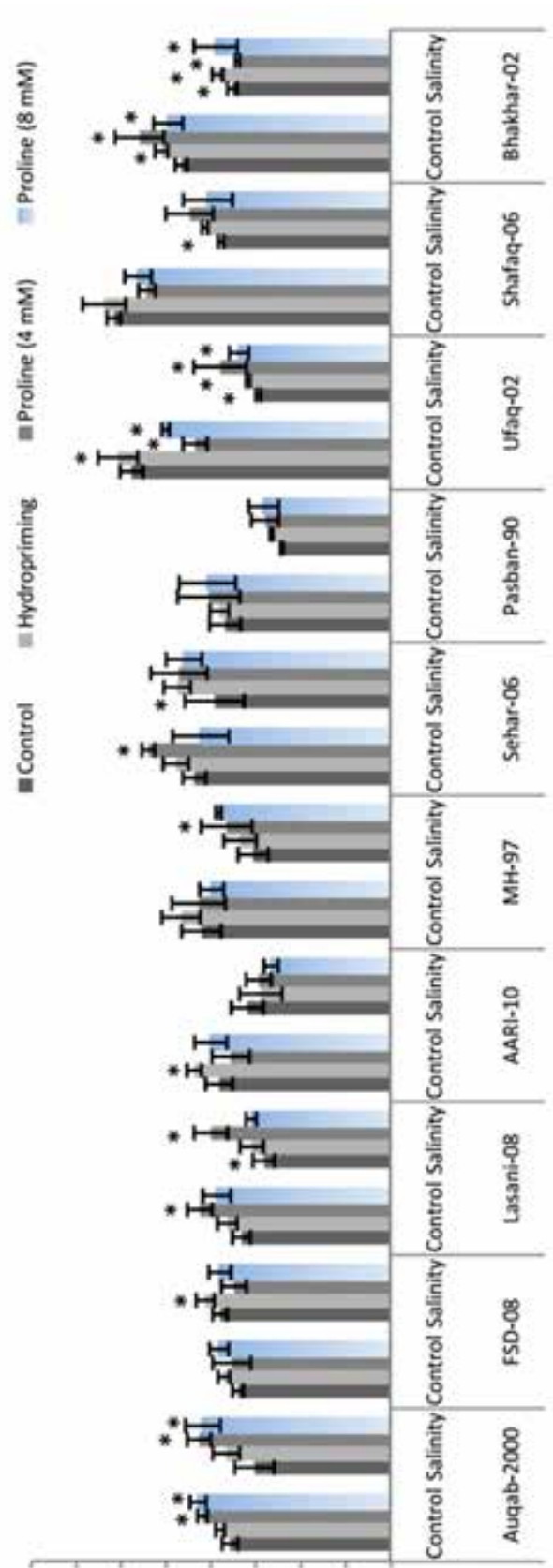

๕

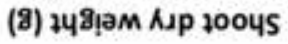

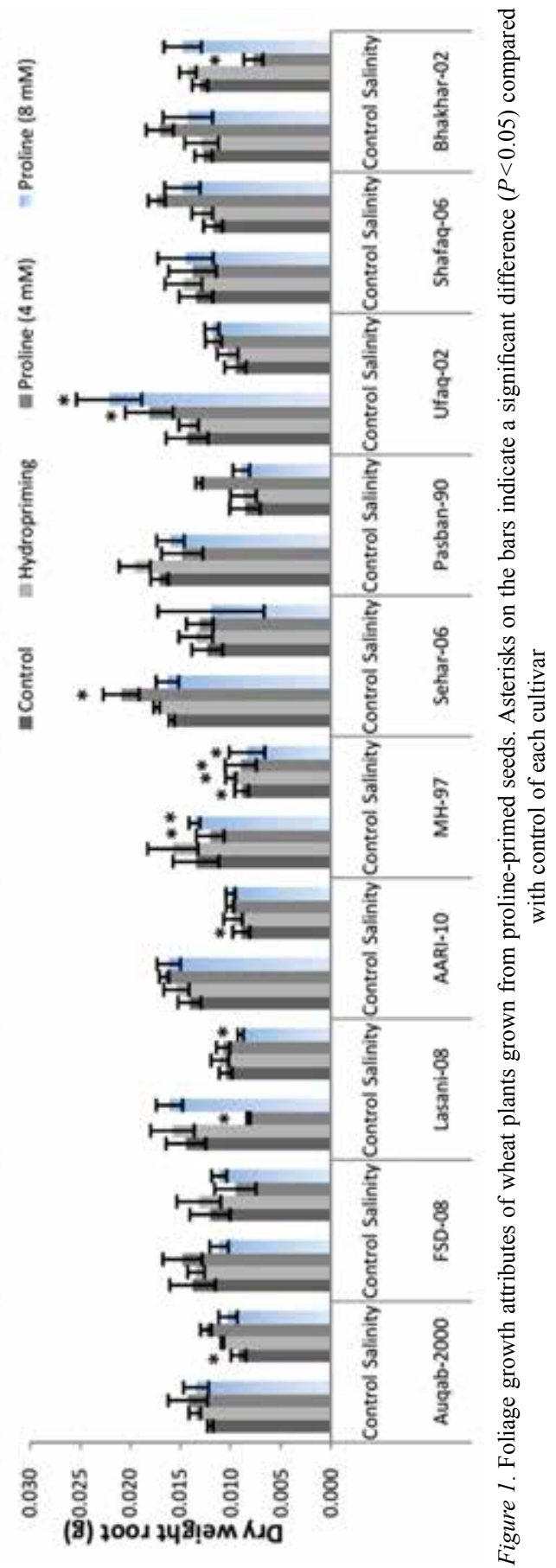

Cereal Research Communications 46, 2018 


\begin{tabular}{|c|c|c|c|c|c|c|c|c|c|c|c|}
\hline \multirow{4}{*}{$\begin{array}{l}\bar{\Xi} \\
\tilde{z} \\
\sum_{\Xi} \\
\stackrel{2}{n}\end{array}$} & 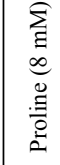 & 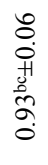 & 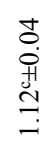 & $\begin{array}{l}n \\
0 \\
0 \\
+1 \\
i n \\
0 \\
0\end{array}$ & $\begin{array}{l}0 \\
0 \\
0 \\
\text { मे } \\
0\end{array}$ & 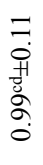 & $\begin{array}{l}n \\
0 \\
0 \\
0 \\
0 \\
0 \\
0 \\
0\end{array}$ & 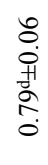 & $\begin{array}{l}\infty \\
0 \\
0 \\
0 \\
0 \\
=\end{array}$ & \begin{tabular}{l} 
oे \\
$\dot{0}$ \\
+1 \\
\multirow{0}{*}{} \\
$\dot{0}$
\end{tabular} & 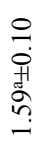 \\
\hline & 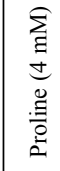 & $\begin{array}{l}n \\
0 \\
\dot{0} \\
+1 \\
\dot{0} \\
\infty \\
\dot{0}\end{array}$ & $\begin{array}{l} \pm \\
0 \\
0 \\
+1 \\
i n \\
0 \\
0 \\
0\end{array}$ & 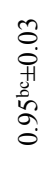 & 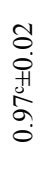 & 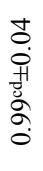 & $\begin{array}{l}8 \\
0 \\
0 \\
\stackrel{+1}{0} \\
\stackrel{0}{+} \\
0\end{array}$ & 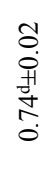 & $\begin{array}{l}\hat{0} \\
\dot{0} \\
+ \\
0 \\
0 \\
0 \\
+\end{array}$ & $\begin{array}{l}n \\
0 \\
0 \\
+1 \\
0 \\
o \\
0 \\
0\end{array}$ & $\begin{array}{l}3 \\
0 \\
0 \\
+1 \\
0 \\
0\end{array}$ \\
\hline & $\begin{array}{l}\text { 总 } \\
\text { 音 } \\
\text { 总 } \\
\text { 离 }\end{array}$ & 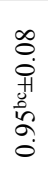 & $\begin{array}{l}n \\
0 \\
0 \\
0 \\
\tilde{0} \\
\tilde{n} \\
\tilde{n}\end{array}$ & $\begin{array}{l}\infty \\
0 \\
0 \\
0 \\
0 \\
0 \\
0 \\
0\end{array}$ & $\begin{array}{l}\text { ப̊. } \\
\stackrel{+}{0} \\
\stackrel{H}{0} \\
\stackrel{0}{0}\end{array}$ & $\begin{array}{l}\dot{\Xi} \\
0 \\
0 \\
+1 \\
\dot{0} \\
\dot{0} \\
\dot{0}\end{array}$ & $\begin{array}{l}\text { t } \\
0 \\
0 \\
+1 \\
0 \\
0\end{array}$ & $\begin{array}{l}0 \\
0 \\
0 \\
0 \\
0 \\
0 \\
\infty \\
0 \\
0\end{array}$ & 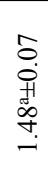 & 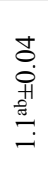 & $\begin{array}{l}\stackrel{8}{0} \\
\text { मे } \\
\stackrel{0}{m}\end{array}$ \\
\hline & $\begin{array}{l}\overline{\dot{\Xi}} \\
\text { Oे }\end{array}$ & 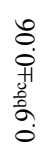 & $\begin{array}{l}\stackrel{2}{0} \\
0 \\
0 \\
0 \\
\stackrel{+}{+} \\
\end{array}$ & $\begin{array}{l}\text { to } \\
\dot{0} \\
+1 \\
0 \\
0 \\
0 \\
0\end{array}$ & $\begin{array}{l}\text { ठ } \\
\stackrel{0}{0} \\
+1 \\
\dot{0} \\
\dot{0}\end{array}$ & $\begin{array}{l}\text { t } \\
\dot{0} \\
+ \\
0 \\
0 \\
0 \\
0\end{array}$ & $\begin{array}{l}0 \\
0 \\
\dot{0} \\
\pm \\
0 \\
0\end{array}$ & $\begin{array}{l}\widetilde{O} \\
0 \\
0 \\
+1 \\
0 \\
0 \\
0\end{array}$ & $\begin{array}{l}\hat{0} \\
\dot{0} \\
+ \\
0 \\
\stackrel{0}{0} \\
\end{array}$ & $\begin{array}{l}\infty \\
0 \\
0 \\
0 \\
+1 \\
\stackrel{1}{0} \\
0\end{array}$ & 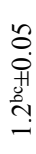 \\
\hline \multirow{4}{*}{$\begin{array}{l}\overrightarrow{0} \\
\text { : }\end{array}$} & 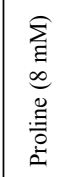 & $\begin{array}{l}\stackrel{0}{0} \\
\dot{0} \\
\dot{H} \\
\dot{0} \\
\dot{0}\end{array}$ & 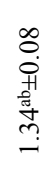 & $\begin{array}{l}\dot{0} \\
0 \\
0 \\
0 \\
\dot{0} \\
\dot{0} \\
\vdots\end{array}$ & 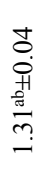 & $\begin{array}{l}0 \\
0 \\
0 \\
0 \\
0 \\
0 \\
0\end{array}$ & $\begin{array}{l}0 \\
0 \\
0 \\
+1 \\
\stackrel{H}{n} \\
=\end{array}$ & 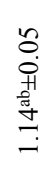 & $\begin{array}{l}\infty \\
0 \\
0 \\
0 \\
0 \\
\infty \\
0 \\
0\end{array}$ & 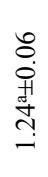 & 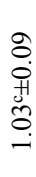 \\
\hline & 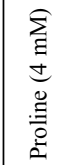 & 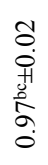 & 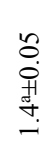 & 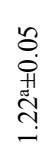 & 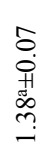 & $\begin{array}{l}n \\
0 \\
0 \\
+\infty \\
\infty \\
n\end{array}$ & $\begin{array}{l}n \\
0 \\
0 \\
0 \\
0 \\
\tilde{\sigma} \\
0\end{array}$ & $\begin{array}{l}\text { oे } \\
\dot{0} \\
\text { H } \\
\text { Oे }\end{array}$ & $\begin{array}{l}\text { Oे } \\
\dot{0} \\
\stackrel{1}{0} \\
\stackrel{0}{=}\end{array}$ & $\begin{array}{l}0 \\
0 \\
0 \\
0 \\
0 \\
\stackrel{1}{2} \\
\vdots \\
0\end{array}$ & $\begin{array}{l}\text { oे } \\
0 \\
01 \\
0 \\
\text { ल } \\
=\end{array}$ \\
\hline & 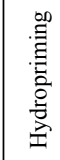 & 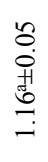 & 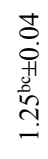 & 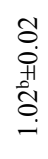 & 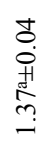 & \begin{tabular}{l}
$\infty$ \\
$\stackrel{0}{0}$ \\
0 \\
+1 \\
\multirow{J}{*}{}
\end{tabular} & $\begin{array}{l}\hat{0} \\
\dot{0} \\
+1 \\
0 \\
\text { 0. }\end{array}$ & 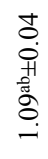 & $\begin{array}{l}\hat{0} \\
0 \\
0 \\
0 \\
0 \\
o \\
0\end{array}$ & 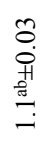 & $\begin{array}{l}\widetilde{O} \\
\stackrel{0}{0} \\
+1 \\
\stackrel{1}{0} \\
0\end{array}$ \\
\hline & 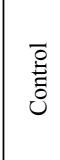 & $\begin{array}{l}n \\
0 \\
0 \\
+1 \\
\text { है } \\
0 \\
0\end{array}$ & $\begin{array}{l}n \\
0 \\
0 \\
+1 \\
0 \\
\pm \\
\end{array}$ & 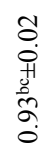 & 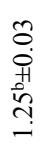 & 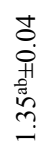 & $\begin{array}{l}0 \\
0 \\
0 \\
0 \\
0 \\
\vdots \\
\vdots\end{array}$ & $\begin{array}{l}\text { J0 } \\
0 \\
0 \\
0 \\
0\end{array}$ & $\begin{array}{l}n \\
0 \\
\dot{0} \\
\dot{H} \\
0 \\
0\end{array}$ & $\begin{array}{l}0 \\
0 \\
0 \\
+1 \\
0 \\
0 \\
0\end{array}$ & 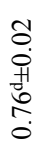 \\
\hline & 岂 & 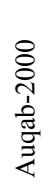 & 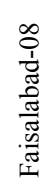 & 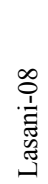 & 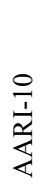 & $\stackrel{\hat{i}}{\stackrel{i}{\Sigma}}$ & 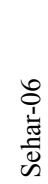 & 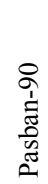 & 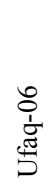 & 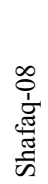 & 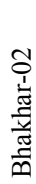 \\
\hline & & \multicolumn{10}{|c|}{ (MH } \\
\hline
\end{tabular}




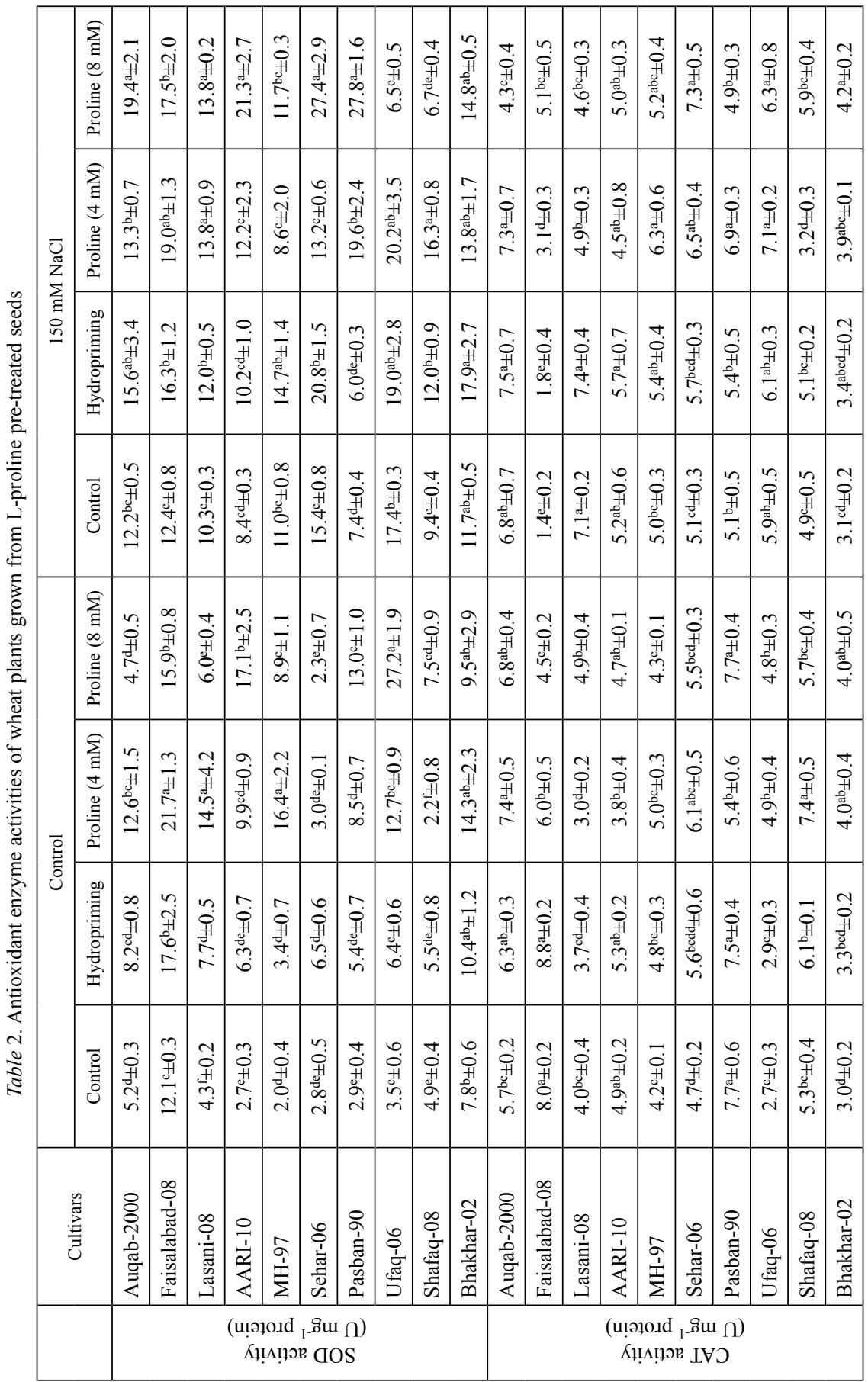




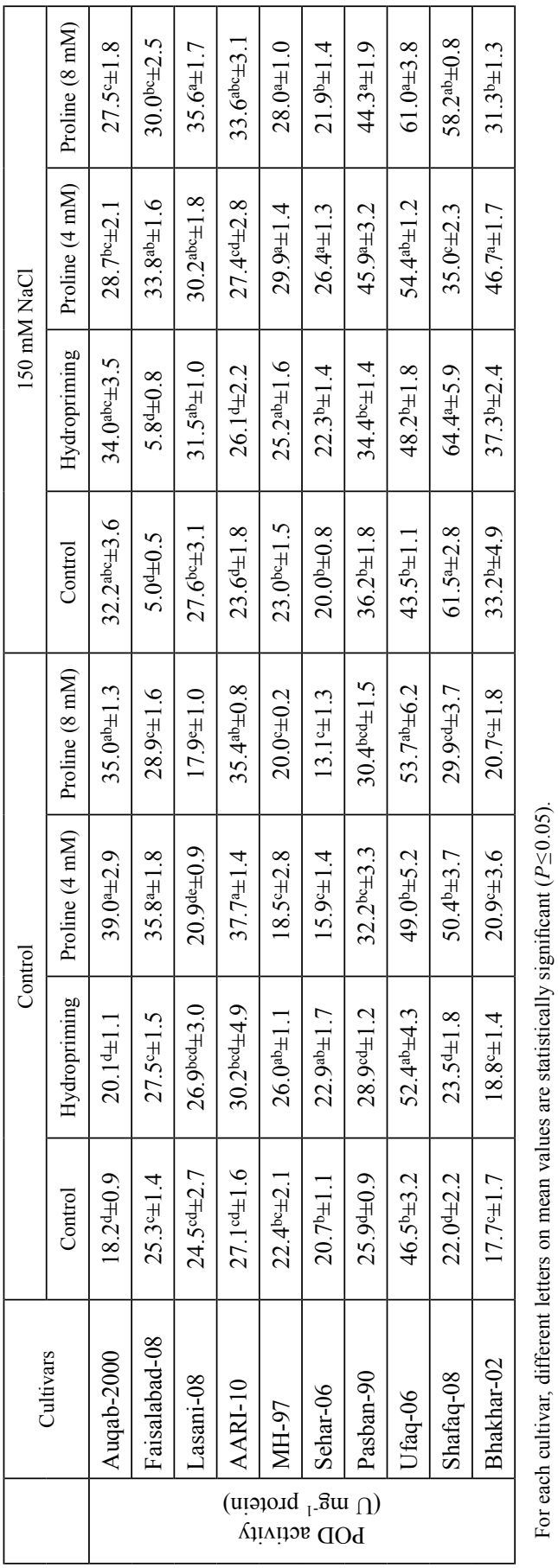



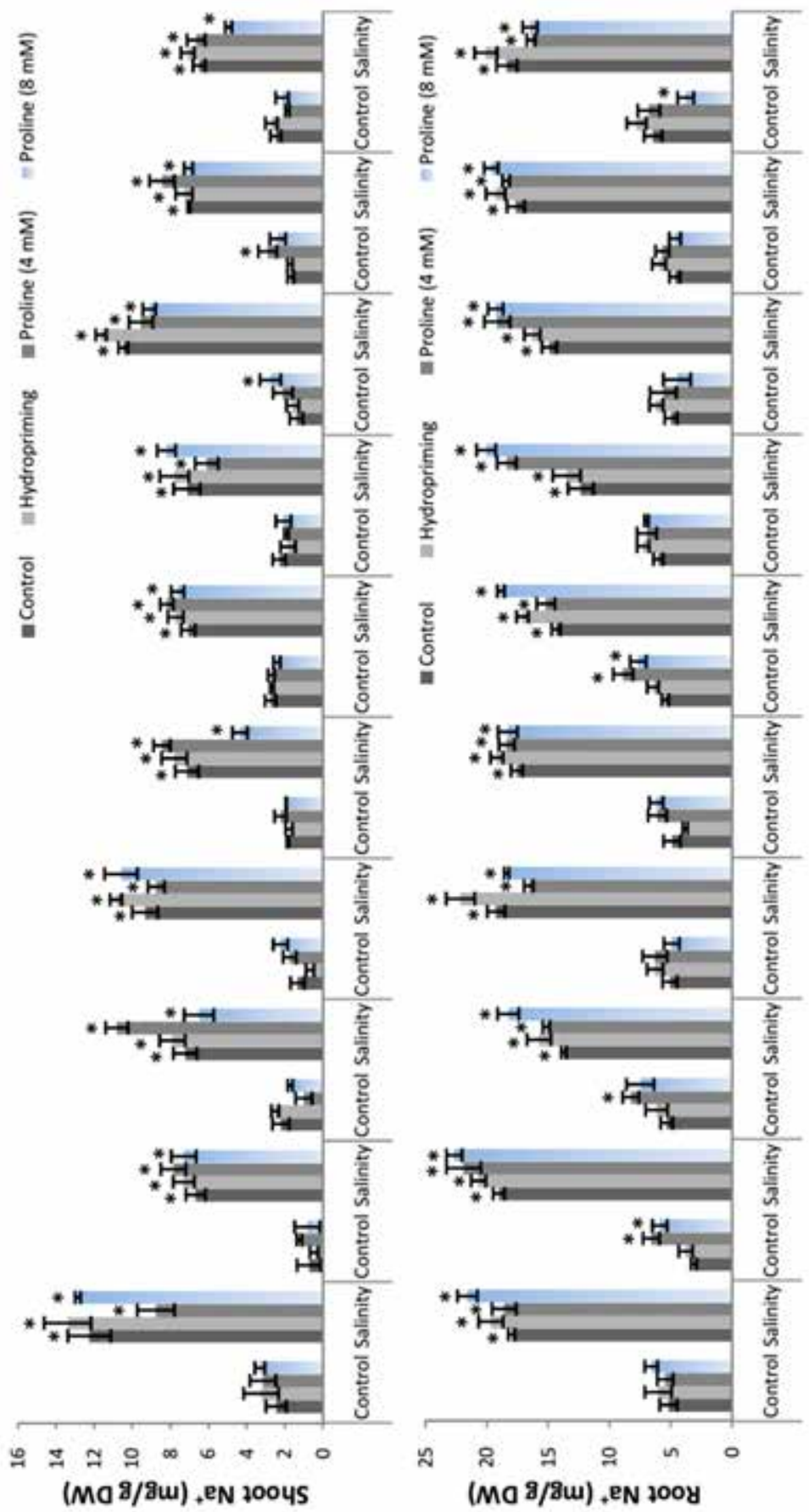

Cereal Research Communications 46, 2018 


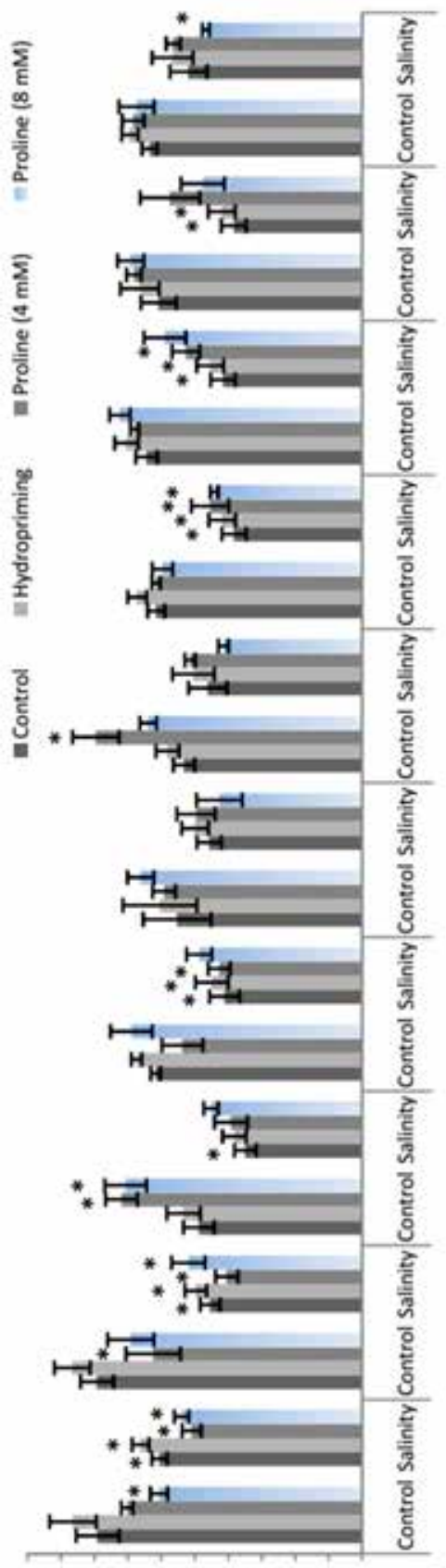

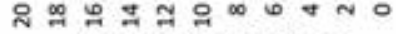
(MO $9 / 8 \mathrm{~m})+\times 720045$

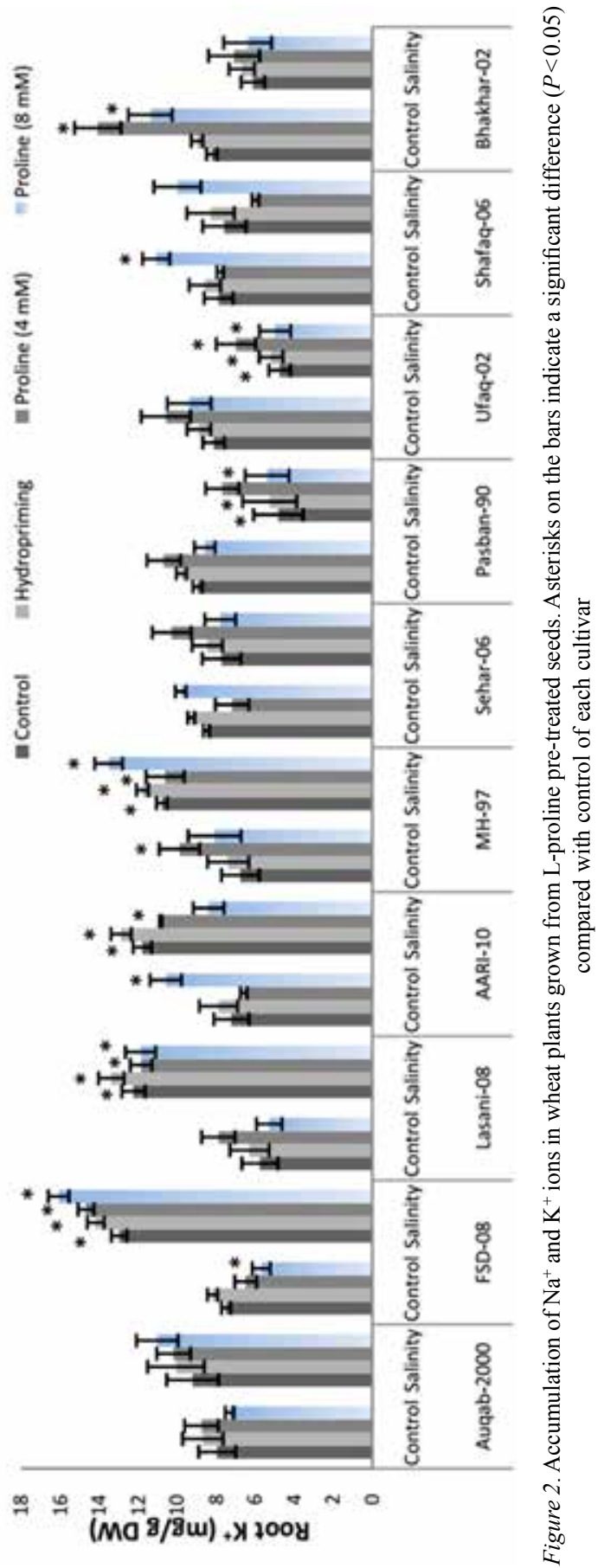

Cereal Research Communications 46, 2018 


\section{Effect of proline seed priming on chlorophyll contents}

Prominent reduction $(P \leq 0.05)$ in the chlorophyll $(\mathrm{Chl})$ contents of wheat seedlings was recorded (Table 1). In general, the addition of $\mathrm{NaCl}(150 \mathrm{mM})$ reduced the $\mathrm{Chl} a$ and $b$ contents of six wheat cultivars (Auqab-2000, Lasani-08, AARI-10, MH-97, Sehar-06 and Pasban-90) while cvs. Fsd-08, Ufaq-06, Shafaq-08 and Bhakhar-02 exhibited rise in the $\mathrm{Chl} a$ contents (Table S1). The total $\mathrm{Chl}$ contents follow the similar trend and maximum $\mathrm{Chl}$ values were recorded in cv. Ufaq-06 and proline seed pre-treatment differentially affected these parameters (Table 1). Prominent correlation between SOD activity and chlorophyll contents was also evident $\left(\mathrm{R}^{2}=0.31 \%\right.$; Table $\left.\mathrm{S} 2\right)$.

\section{Effect of proline seed priming on antioxidant enzyme activities}

Salinity increased the SOD activity of all cultivars except cv. FSD-08. Maximum values were recorded in cv.Ufaq-02 while least in cv. Pasban-90 $(P \leq 0.05)$. The effect of proline seed priming on SOD activity of wheat plants greatly varied among cultivars and it was concentration dependent (Table 2). Likewise, prominent increase $(P \leq 0.05)$ in the CAT activity of wheat plants was recorded in $150 \mathrm{mM} \mathrm{NaCl}$ stress except for cvs. Fsd-08, Pasban-90 and Bhakhar-02 where it significantly reduced. Under salinity, proline (4 mM) significantly improved the CAT activity of cvs. Auqab-2000, Fsd-08, MH-97, Sehar-06, Pasban-90 and Ufaq-02. While at $8 \mathrm{mM}$, it improved the CAT activity of cvs. Fsd-08, Sehar-06, Ufaq-02, Shafaq-06 and Bhakhar-02 (Table 2). Likewise, progressive increase in the guaicaol-dependent POD activity of cvs. Auqab-2000, Lasani-08, MH-97, Pasban-90, Shafaq-06 and Bhakhar-02 were recorded under salinity. In contrast, the reduction in POD activity under salt stress was evident for cvs. Fsd-08, AARI-10, Sehar-06 and Ufaq-06. The proline seed pre-treatment ( 4 and $8 \mathrm{mM}$ ) differentially improved the POD activity of all the cultivars except Auqab-2000 and Shafaq-06 (Table 2). In addition, the native-PAGE confirmed the induction of POD isoforms under salt stress (Fig. S3).

\section{Effect of proline seed priming uptake of sodium and potassium ions}

Significant increase $(P \leq 0.05)$ in the root and shoot $\mathrm{Na}^{+}$contents was recorded among all the cultivars under salinity stress. Higher root $\mathrm{Na}^{+}$contents were recorded in cvs. AARI10, Fsd-08 and Bhakhar-02 while least values in cv. Pasban-90 (Fig. 2). Similarly, higher shoot $\mathrm{Na}^{+}$contents were recorded for cv. Auqab-2000 followed by cvs. Ufaq-06 and AARI-10. On the other hand, an increase in the root $\mathrm{K}^{+}$contents was recorded for cvs. Auqab-2000, Fsd-08, Lasani-08, AARI-10 and MH-97 (Fig. 2). The root $\mathrm{K}^{+}$contents of cvs. Sehar-06, Pasban-90, Ufaq-06, Shafaq-08 and Bhakhar-02 exhibited reduction $(P \leq 0.05)$ under salinity stress. Shoot potassium contents were significantly correlated with root FW $\left(\mathrm{R}^{2}=0.46^{*}\right)$ while root potassium was positively linked with shoot $\mathrm{FW}$ $\left(\mathrm{R}^{2}=0.55^{* *}\right.$; Table $\left.\mathrm{S} 2\right)$. On the other hand, shoot potassium contents were positively linked with shoot FW $\left(\mathrm{R}^{2}=0.45^{* *}\right)$, root and shoot $\mathrm{Na}^{+}$contents $\left(\mathrm{R}^{2}=0.35^{*}\right.$ and $\left.0.38^{*}\right)$. Likewise, root $\mathrm{K}^{+}$contents were positively linked with root and shoot length $\left(\mathrm{R}^{2}=0.45^{*}\right.$ 
and $0.43 *)$. Above all, root $\mathrm{K}^{+}$was positively connected to root $\mathrm{Na}^{+}$contents $\left(\mathrm{R}^{2}=0.41 *\right)$ while negatively correlated with POD activity $\left(\mathrm{R}^{2}=-0.52 * *\right)$.

\section{Discussion}

Salinity resulted in prominent reduction in the shoot and root growth attributes while the magnitude of growth retardation varied among cultivars. Salinity induced reduction in the growth features has already been reported earlier in wheat (Raza et al. 2007; Iqbal and Ashraf 2013) and is linked with altered plant nutrient uptake, insufficient water availability affecting osmotic potential and ionic balance / toxicity (Munns and Tester 2008). In this study, plants grown from proline primed seed exhibited improved growth attributes although the response varied among cultivars. The compatible solutes play vital role in the osmotic balance under stressed conditions. Proline is an important osmolyte and its role in counteracting stress-induced effects is very significant (Ueda et al. 2007; Szabados and Savoure 2009; Miller et al. 2009).

Antioxidant enzyme activities of salt stressed wheat plants greatly increased. Although cultivar variation was evident, the results indicated an increase in the antioxidant activity of SOD, POD and CAT enzymes. Salinity initiated physiological disturbances through enhanced production of reactive oxygen species (Apel and Hirt 2004) which are subsequently kept at steady levels by antioxidant enzymes (Mittler 2006). The enzyme SOD constitutes the first line of antioxidant defense and it dismutase superoxide radical into $\mathrm{H}_{2} \mathrm{O}_{2}$ and $\mathrm{O}_{2}$ (Mittler 2006) and also contributes to up-and downstream regulation of other enzymes (Alscher et al. 2002). In addition, the effect of proline seed pre-treatment on the antioxidant enzyme activity of SOD, CAT and POD was substantial although varied among cultivars. Several studies linked antioxidant capacity with oxidative stress and salinity tolerance (Hernández et al. 2000; Mittler 2006; Raza et al. 2014). The increase in the antioxidant enzyme activities of salt stressed wheat plants in the present study was attributed to the regulation of salinity-mediated oxidative stress.

Salt-induced reduction in the chlorophyll contents was also recorded for six cultivars except cvs. Fsd-08, Ufaq-06, Shafaq-08 and Bhakhar-02. The reduction of the chlorophyll contents are consistent with previous reports (Raza et al. 2007; Averina et al. 2010). Wheat cultivars showed differential response towards accumulation of $\mathrm{Na}^{+}$ions in the root and its subsequent translocation to the shoot under $\mathrm{NaCl}$ stress. The cvs. Fsd- 08 and Bhakhar-02 accumulated highest $\mathrm{Na}^{+}$in the root in comparison with other cultivars. Interestingly, both the cultivars exhibited minimum shoot $\mathrm{Na}^{+}$contents possibly due to having less efficient $\mathrm{Na}^{+}$translocation system. Lesser accumulation of $\mathrm{Na}^{+}$ions in the leaves is an important attribute which relates with salt resistance of wheat (Munns and James 2003) that usually depends on $\mathrm{Na}^{+} / \mathrm{K}^{+}$ratio (Munns et al. 2012; Roy et al. 2014). Similarly, variations in the $\mathrm{K}^{+}$ions were also recorded for different cultivars with respect to its accumulation in the shoots and roots. Of the ten cultivars tested, five (Auqab-2000, FSD-08, Lasani-08, AARI-10 and MH-97) exhibited rise in the root $\mathrm{K}^{+}$contents while the other five exhibited reduction in the root $\mathrm{K}^{+}$contents. In addition, reduction in the shoot 
$\mathrm{K}^{+}$contents was evident for all the wheat cultivars. Although proline seed priming improved the root and shoot $\mathrm{K}^{+}$contents, the effect was dose and cultivar dependent.

Shoot length was negatively correlated with shoot $\mathrm{Na}^{+}\left(\mathrm{R}^{2}=-0.56 * *\right)$ and root $\mathrm{Na}$ $\left(\mathrm{R}^{2}=-0.60 * *\right)$ while positively linked with shoot $\mathrm{K}^{+}\left(\mathrm{R}^{2}=0.62 * *\right)$. Similarly, root length was negatively correlated with shoot $\mathrm{Na}^{+}\left(\mathrm{R}^{2}=-0.71 * *\right)$ and root $\mathrm{Na}^{+}\left(\mathrm{R}^{2}=-0.74 * *\right)$ while positively linked with shoot $\mathrm{K}^{+}\left(\mathrm{R}^{2}=0.66 * *\right)$. Root $\mathrm{Na}^{+}$contents were prominently correlated with shoot $\mathrm{Na}^{+}\left(\mathrm{R}^{2}=0.88 * * *\right)$. The $\mathrm{Na}^{+}$in shoot and root significantly correlated with SOD activity $\left(\mathrm{R}^{2}=0.42 *\right.$ and $\left.0.47 *\right)$. Significant negative correlation between shoot $\mathrm{K}^{+}$and root and shoot $\mathrm{Na}^{+}$was evident $\left(\mathrm{R}^{2}=-0.65^{* *}\right.$ and $\left.-0.70 * *\right)$. Of the ten wheat cultivars investigated, cvs. FSD-08 and Bhakhar-02 were ranked as relatively salt tolerant, cvs. Ufaq-06, Shafaq-08, Pasban-90, Lasani-08 and Sehar-06 as moderately salt tolerant and cvs. AARI-10, MH-97 and Auqab-2000 as salt sensitive. Furthermore, cv. Fsd-08 exhibited reduction in CAT and POD activities, increase in chlorophyll contents, higher root $\mathrm{Na}^{+}$and $\mathrm{K}^{+}$contents and lower shoot $\mathrm{Na}^{+}$contents, and thus the mechanism of salt tolerance in this cultivar during osmotic phase was independent of antioxidant enzyme activities and were based on improved chlorophyll, lesser $\mathrm{Na}^{+}$shoot translocation and root ion adjustment through increased $\mathrm{K}^{+}$uptake. In contrast, cv. Bhakhar- 02 seemed to be reliant on both $\mathrm{Na}^{+}$partitioning in the root and the activities of enzymatic antioxidants.

\section{Acknowledgements}

The study was funded by the Higher Education Commission (HEC), Pakistan through Project No: $20-1542 / R \& D / 09 / 2519$ to Dr. Syed Hammad Raza.

\section{References}

Aebi, H. 1984. Catalase. In: L. Packer (ed.), Methods in enzymology, Academic Press.Orlando, FL, USA. 105: $121-126$.

Alscher, R.G., Erturk, N., Heath, L.S. 2002. Role of superoxide dismutases (SODs) in controlling oxidative stress. J. Exp. Bot. 53:1331-1341.

Apel, K., Hirt, H. 2004. Reactive oxygen species, metabolism, oxidative stress and signal transduction. Ann. Review Plant Biol. 55:373-399.

Arnon, D.I. 1949. Copper enzymes in isolated chloroplasts. Polyphenoloxidase in Beta vulgaris. Plant Physiol. 24:1-10.

Averinaa, N.G., Gritskevicha, E.R., Vershilovskayaa, I.V., Usatovb, A.V., Yaronskaya, E.B. 2010. Mechanisms of salt stress tolerance development in barley plants under the influence of 5-amino-levulinic acid. Russ. J. Plant Physiol. 57:792-798.

Chance, B., Maehly, A.C. 1955. Assay of catalases and peroxidases. Meth. Enzymol. 2:764-775.

Daliakopoulos, I.N., Tsanis, I.K., Koutroulis, A., Kourgialas, N.N., Varouchakis, A.E., Karatzas, G.P., and Ritsema, C.J. 2016. The threat of soil salinity: A European scale review. Sci. Total Environ. 573:727-739.

Dhanda, S.S., Sethi, G.S., Behl, R.K. 2004. Indices of drought tolerance in wheat genotypes at early stages of plant growth. J. Agron. Crop Sci. 190:6-12.

FAO 2008. FAO land and plant nutrition management service. http://www.fao.org/ag/agl/agll/spush.

Forni, C., Duca, D., Glick, B.R. 2017. Mechanisms of plant response to salt and drought stress and their alteration by rhizobacteria. Plant Soil. 410:335-356. 
Giannopolitis, C.N, Ries, S.K. 1977. Superoxide dismutases, purification and quantitative relationship with water-soluble protein in seedlings. Plant Physiol. 59:315-318.

Hernández, J., Jimenez, A., Mullineaux, P., Sevilla, F. 2000. Tolerance of pea plants (Pisum sativum) to long term salt stress is associated with induction of antioxidant defenses. Plant Cell Environ. 23:853-862.

Hernandez, M., Garcia, N.F., Vivancos, P.D., Olmos, E. 2009. A different role for hydrogen peroxide and the antioxidative system under short and long salt stress in Brassica oleracea roots. J. Exp. Bot. 61:521-535.

Iqbal, M., Ashraf, M. 2013. Gibberellic acid mediated induction of salt tolerance in wheat plants: Growth, ionic partitioning, photosynthesis, yield and hormonal homeostasis. Environ. Exp. Bot. 86:76-85.

Koevoets, I.T., Venema, J.H., Elzenga, J.T.M., Testerink, C. 2016. Roots withstanding their environment: exploiting root system architecture responses to abiotic stress to improve crop tolerance. Frontiers Plant Sci. 1-7.

Laemmli, U.K. 1970. Cleavage of structural proteins during the assembly of the head of bacteriophage $\mathrm{T}_{4}$. Nature 227:680-685.

Miller, G., Honig, A., Stein, H., Suzuki, N., Mittler, R., Zilberstein, A. 2009. Unraveling delta1-pyrroline5-carboxylate (P5C)/proline cycle in plants by uncoupled expression of proline oxidation enzymes. J. Biol. Chem. 284:26482-26492.

Mittler, R. 2002. Oxidative stress, antioxidants and stress tolerance. Trends Plant Sci. 7:405-410.

Mittler, R. 2006. Abiotic Stress, the field environment and stress combination. Trends Plant Sci. 11:15-19.

MSTAT Development Team 2013. MSTAT User's Guide: A Microcomputer Program for the Design Management and Analysis of Agronomic Research Experiments. Michigan State University. East Lansing, MC, USA.

Munns, R, James, R.A. 2003. Screening methods for salinity tolerance: A case study with tetraploid wheat. Plant Soil 253:201-218.

Munns, R, Tester, M. 2008. Mechanisms of salinity tolerance. Ann. Rev. Plant. Biol. 59:651-681.

Munns, R. 2002. Comparative physiology of salt and water stress. Plant Cell Environ. 25:239-250.

Munns, R., James, R.A., Xu, B., Athman, A., Conn, S.J., Jordans, C., Byrt, C.S., Hare, R.A., Tyerman, S.D., Tester, M., Plett, D., Gilliham, M. 2012. Wheat grain yield on saline soils is improved by an ancestral $\mathrm{Na}^{+}$ transporter gene. Nature Biotech. 30:360-364.

Murtaza, B., Murtaza, G., Sabir, M., Owens, G., Abbas, G., Imran, M., Shah, G.M. 2017. Amelioration of saline-sodic soil with gypsum can increase yield and nitrogen use efficiency in rice-wheat cropping system. Arch. Agron. Soil Sci. 63:1267-1280.

Raza, S.H., Athar, H.R., Ashraf, M., Hameed, A. 2007. Glycine betaine-induced modulation of antioxidant enzymes activities and ion accumulation in two wheat cultivars differing in salt tolerance. Environ. Exp. Bot. 3:368-376.

Raza, S.H., Ahmad, M.B., Ashraf, M.A., Shafiq, F. 2014. Time-course changes in growth and biochemical indices of mung bean [Vigna radiata (L.) Wilczek] genotypes under salinity. Braz. J. Bot. 37:429-439.

Robin, A.H.K., Matthew, C., Uddin, M.J., Bayazid, K.N. 2016. Salinity-induced reduction in root surface area and changes in major root and shoot traits at the phytomer level in wheat. J. Exp. Bot. 67:3719-3729.

Roy, S., Negrao, S., Tester, M. 2014. Salt resistant crop plants. Curr. Opinion Biotech. 26:115-124.

Schleiff, U. 2008. Analysis of water supply of plants under saline soil conditions and conclusions for research on crop salt tolerance. J. Agron. Crop. Sci. 194:1-8.

Sileshi, A.A., Kibebew, K. 2016. Status of salt affected soils, irrigation water quality and land suitability of Dubti/Tendaho area, North Eastern Ethiopia. Doctoral dissertation, Haramaya University. Alemaya, Ethiopia.

Szabados, L.S., Savoure, A. 2009. Proline, a multifunctional amino acid. Trends Plant Sci. 15:89-97.

Ueda, A., Yamamoto-Yamane, Y., Takabe, T. 2007. Salt stress enhances proline utilization in the apical region of barley roots. Biochem. Biophysics Res. Commun. 355:61-66.

Van Loon, L.C. 1971. Tobacco polyphenoloxidase: A specific staining method indicating non-identify with peroxidases. Phytochem. 10:503-507.

Wolf, B.A. 1982. Comprehensive system of leaf analysis and its use for diagnosing crop nutrients status. Commun. Soil Sci. Plant Anal. 13:1035-1059. 


\section{Electronic Supplementary Material (ESM)}

Electronic Supplementary Material (ESM) associated with this article can be found at the website of CRC at http://www.akademiai.com/content/120427/

Electronic Supplementary Table S1. Chlorophyll $a$ and $b$ contents of wheat plants grown from proline primed seeds

Electronic Supplementary Table S2. Pearson correlation coefficients for various attributes of wheat plants grown from proline primed seeds under control conditions

Electronic Supplementary Table S3. Pearson correlation coefficients for various attributes of wheat plants grown from proline primed seeds under salinity

Electronic Supplementary Figure S1. Foliage growth attributes of wheat plants grown from proline primed seeds. Asterisks on the bars indicate a significant difference $(P<0.05)$ compared with control of each cultivar

Electronic Supplementary Figure S2. Root growth attributes of wheat plants grown from proline primed seeds. Asterisks on the bars indicate a significant difference $(P<0.05)$ compared with control of each cultivar

Electronic Supplementary Figure S3. Guaiacol-type POD activity of plants using Native-PAGE. Auqab-2000 (1), FSD-08 (2), Lasani-08 (3), AARI-10 (4), MH-97 (5), Sehar-2006 (6), Pasban-90 (7), Ufaq-2006 (8), Shafaq-2008 (9), Bhakhar-02 (10) 